\title{
Forecasting next season's Ixodes ricinus nymphal density: the example of southern Germany 2018
}

\author{
Katharina Brugger ${ }^{1}$ (D) Melanie Walter ${ }^{1} \cdot$ Lidia Chitimia-Dobler $^{2,3}$. \\ Gerhard Dobler $^{2,3,4} \cdot$ Franz Rubel $^{1}$
}

Received: 3 April 2018 / Accepted: 18 May 2018 / Published online: 30 May 2018

(C) The Author(s) 2018

\begin{abstract}
The castor bean tick, Ixodes ricinus (L.) (Ixodida: Ixodidae), is the principal vector of pathogens causing tick-borne encephalitis or Lyme borreliosis in Europe. It is therefore of general interest to make an estimate of the density of I. ricinus for the whole year at the beginning of the tick season. There are two necessary conditions for making a successful prediction: a long homogeneous time series of observed tick density and a clear biological relationship between environmental predictors and tick density. A 9-year time series covering the period 2009-2017 of nymphal I. ricinus flagged at monthly intervals in southern Germany has been used. With the hypothesis that I. ricinus density is triggered by the fructification of the European beech 2 years before, the mean annual temperature of the previous year, and the current mean winter temperature (December-February), a forecast of the annual nymphal tick density has been made. Therefore, a Poisson regression model was generated resulting in an explained variance of $93.4 \%$ and an error of RMSE $=21$ ticks per $100 \mathrm{~m}^{2}$ (annual MEAN $=260$ collected ticks $/ 100 \mathrm{~m}^{2}$ ). An independent verification of the forecast for the year 2017 resulted in 187 predicted versus 180 observed nymphs per $100 \mathrm{~m}^{2}$. For the year 2018 a relatively high number of 443 questing I. ricinus nymphs per $100 \mathrm{~m}^{2}$ is forecasted, i.e., a "good" tick year.
\end{abstract}

Keywords Tick-borne diseases - Tick-borne encephalitis $\cdot$ Lyme borreliosis $\cdot$ Mast seeding $\cdot$ Fructification

Gerhard Dobler and Franz Rubel have contributed equally to this work.

Katharina Brugger

katharina.brugger@vetmeduni.ac.at

1 Institute for Veterinary Public Health, University of Veterinary Medicine Vienna, Veterinärplatz 1, 1210 Vienna, Austria

2 Bundeswehr Institute of Microbiology, Neuherbergstraße 11, 80937 Munich, Germany

3 German Center of Infection Research (DZIF), Partner Site Munich, Munich, Germany

4 Parasitology Unit, University of Hohenheim, Emil-Wolff-Straße 34, 70593 Stuttgart, Germany 


\section{Introduction}

The question whether or not the upcoming year will be a tick year in Europe, i.e., a year with many Ixodes ricinus (L.) (Ixodida: Ixodidae) ticks, comes up every spring. If reliable such a forecast would be of great interest for any nature lover, but also for dog owners. This also rises the question whether from such an annual assessment directly the risk level of getting a tick-borne disease such as tick-borne encephalitis (TBE) or Lyme borreliosis (LB) can be derived regardless of other influencing factors.

With four live stages (egg, larva, nymph, and adult) and a life span of up to several years (Gray et al. 2016), a prediction on how the biological system I. ricinus will behave over the next few days, months or even years is rather complex. Each time scale has its own challenges and its own accuracy, as already known from meteorology forecasts with different forecast ranges (World Meteorological Organization 2010). The weather situation and all the relevant parameters can be described in detail for the next $2 \mathrm{~h}$ (nowcasting) or for the next 12-72 h (short-range forecasting). Otherwise the weather situation can be described less detailed for a period beyond 3 and up to 10 days (medium-range forecast). For periods from 30 days up to 2 years (long-range forecast) averages or deviations are given.

Applied for ticks, short-range forecasts of tick activity cover up to 1 week ahead and should be regularly updated. Influenced mainly by the actual weather, an estimate of tick activity including probable significant changes has to be given. Until now different methods were presented to forecast tick activity in European countries. Temperature and relative humidity turned out to be the main predictors for all methods. While the TICKPRO program releases a single estimate the daily tick activity for the Czech Republic (Daniel et al. 2010), the FleaTickRisk (Beugnet et al. 2009) as well as the TEKENRADAR model (Garcia-Martí et al. 2017) provide a spatial estimate of the tick activity weekly for Europe and daily for The Netherlands, respectively. Only the previous weekly forecasts for Germany provided by the company TICK-RADAR also considered the recent host-seeking tick activity by observing ticks in field plots (Kahl and Dautel, personal communication). Short-range forecasts of tick activity can be used to derive also the risk of acquiring a tickborne infection for exposed people.

On the other hand, long-range forecasts of tick density covering the coming months or years are still missing. Note that, for these longer time periods short-time or inter-daily fluctuations are not considered. Therefore, long-range forecasts can be interpreted as a guide for decision-making over a longer period. One important requirement for developing long-range forecasts, i.e. predictions of the annual tick density, is an existing monitoring of monthly tick activity over long periods. Although in Germany time series of regularly flagged nymphal ticks at 69 sites are available (Brugger et al. 2016), the majority covers only 2-3 years. So far, the time series of the site Haselmühl (Bavaria, Germany) is the longest with nine consecutive years without data gaps. Time series of comparable lengths such as those from Daniel et al. (2015) or Takken et al. (2017) are seldom or not yet published (Kahl and Dautel, personal communication). The Haselmühl time series was already used to demonstrate that the seasonal inter-annual fluctuations of tick activity are most affected by time-lagged and temporal averaged variables, such as temperature and precipitation, rather than by contemporaneous variables (Brugger et al. 2017a). Here we use the available time series to quantify the influence of biotic and abiotic variables on the annual nymphal $I$. ricinus density and to forecast the next year's density. Beside time-lagged meteorological variables, also the fructification of European beeches (Fagus sylvatica), i.e. the annual seed production, was used. The boosting effect 2 years after a mast seeding on the 
nymphal density is a long-known concept, e.g for I. scapularis in the USA (Ostfeld et al. 1996).

The aim of this work is to determine whether a reliable forecast of the tick density for a given location at the beginning of the tick season is possible. Which biotic and abiotic parameters can be used to forecast the next year's nymphal tick density? Using the example of the sampling site Haselmühl, a first guess to predict the next year's annual nymphal $I$. ricinus density is undertaken.

\section{Materials and methods}

\section{Time series of nymphal tick densities and environmental variables}

For the analysis we used the data set of the site Haselmühl, a time series of monthly nymphal ticks per $100 \mathrm{~m}^{2}$ for the period 2009-2017. The site as well as the flagging procedure has been described in detail by Brugger et al. (2017a). Here the main focus is on the I. ricinus nymphs as this stage plays an important role in the epidemiology of human infections (Gray 1998). Note that, the annual nymphal density is the total number of I. ricinus nymphs monthly collected per $100 \mathrm{~m}^{2}$ during 1 year.

Climate variables were taken from the nearest weather station Regensburg-Oberhub (WMO No. 107760) of the German Weather Service (2018). For the period 2007-2017, time series of annual mean values as well seasonal means (i.e. Dec-Jan-Feb, Mar-April-May, June-July-Aug, Sep-Oct-Nov) for the variables temperature and precipitation were aggregated out of daily measurements.

The density of ticks depends also on the availability of suitable hosts. Preferred hosts of I. ricinus larvae and nymphs are among others small rodents (Mihalca and Sándor 2013). As no perennial observations of small rodents are available for the study site Haselmühl, the fructification index of the European beech (Fagus sylvatica) was applied for indicating the rodent density. Beechnuts are a basic food source for small rodents resulting in population peaks 1 year after mast seeding (Ostfeld et al. 1996; Clement et al. 2009). Given the importance of forestry in Bavaria, this annual index is available back to 1954 (Kronnert et al. 2016). Fructification is defined as the annual seed production and is divided into four classes according to Eichhorn et al. (2017): (1) absent, i.e. no fructification, (2) scarce, i.e. sporadic occurrence of fructification, but not noticeable at first sight, (3) common, i.e. clearly visible fructification, and (4) abundant, i.e. full fructification, also known as mast seeding.

\section{Statistical analysis}

In a first step the correlation coefficients between the annual nymphal I. ricinus density and environmental variables were calculated. As some variables are not normally distributed, the Spearman's rank order correlation coefficient was applied. Additionally, time-lags of 1 and 2 years previous were considered to identify the highest correlation. Finally, a Poisson regression model for the annual nymphal tick density was developed, whereas nonsignificant variables were removed in a stepwise procedure. Accounting the overdispersion of the time series, a quasi-Poisson GLM was used to correct the standard errors (Zuur et al. 2009). The coefficient of determination for generalised linear models $R^{2}$ and the root mean square error (RMSE) were applied as goodness-of-fit measures. 
All analyses were conducted with the open-source statistical computing environment $\mathrm{R}$ (R Development Core Team 2018). The package rsq (Zhang 2016) was used for calculating the coefficient of determination $\mathrm{R}^{2}$.

\section{Results}

To forecast the nymphal I. ricinus density of the next year, a quasi-Poisson model was derived with the mean winter temperature of the months December to February $\mathrm{T}_{D J F}$, the mean annual temperature of the previous year $\mathrm{T}_{\text {year-1 }}$, as well as the beech fructification index 2 years prior $\mathrm{F}_{\text {year }-2}$ as indicated in Table 1 . The model results in an explained variance of $93.4 \%$ and an RMSE of 21 ticks per year. The latter is equivalent to $8 \%$ of the mean collected annual tick density of 260 nymphs $/ 100 \mathrm{~m}^{2}$. As depicted in Fig. 1, the model simulated the annual nymphal tick density with peaks almost every second year fairly accurately. After a year with relative low tick density below 200 nymphs per $100 \mathrm{~m}^{2}$ in 2017 an annual density of 443 nymphs per $100 \mathrm{~m}^{2}$ was estimated for 2018 (Fig. 1). This forecast
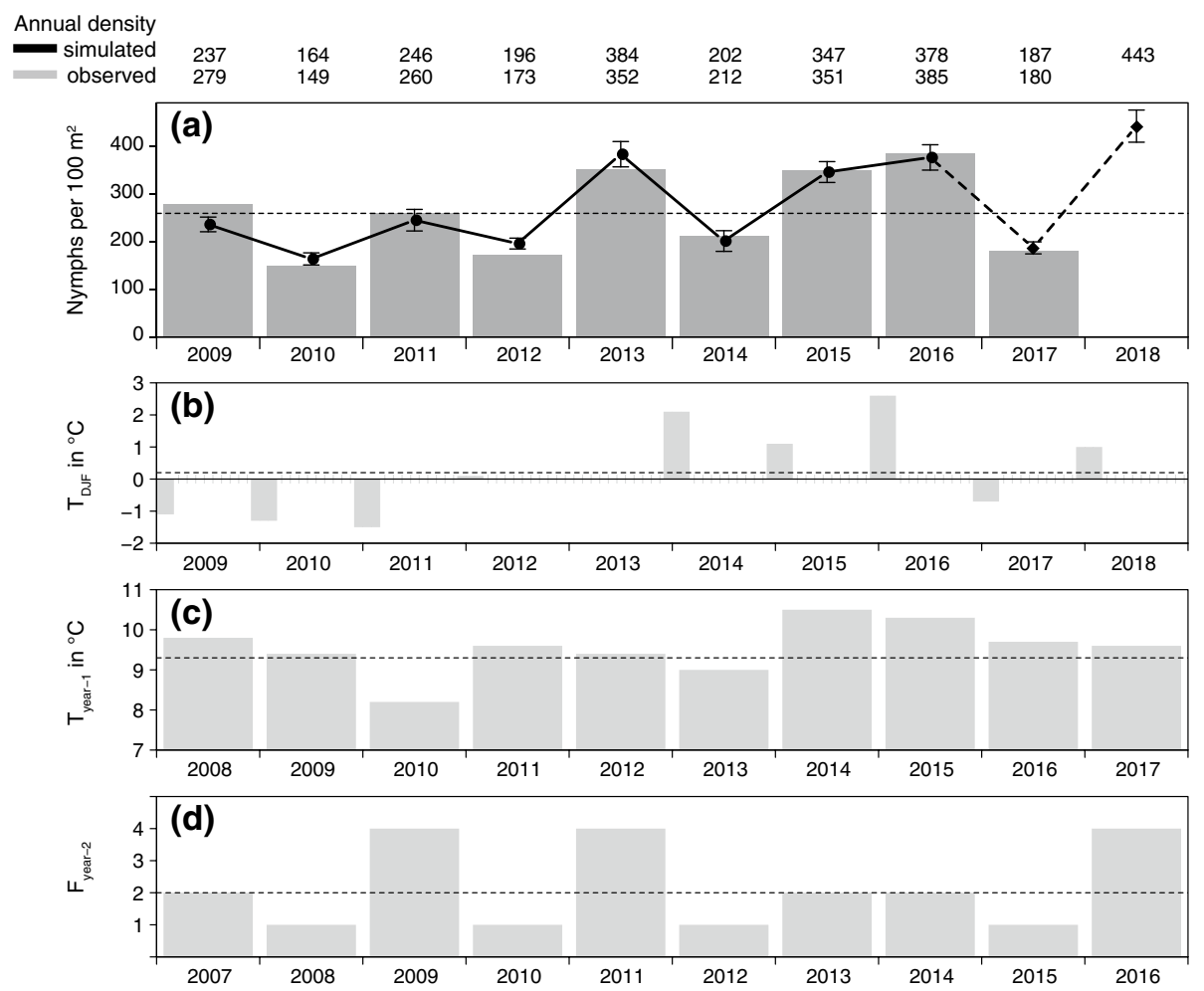

Fig. 1 a Annual nymphal Ixodes ricinus density in Haselmühl (Germany) observed (grey bars) versus simulated (points) between 2009-2017 and forecasted for 2018 (diamond). The associated standard error is given. The explanatory variables $\mathbf{b}$ mean winter temperature $\mathrm{T}_{D J F}$, $\mathbf{c}$ mean annual temperature of the previous year $\mathrm{T}_{\text {year }-1}$, and $\mathbf{d}$ the beech fructification index 2 years prior $\mathrm{F}_{\text {year }-2}$. The dotted lines indicate the 9-year mean between 2009-2017 for the nymphal tick density and the 30-year mean of 1988-2017 for explanatory variables, respectively 
Table 1 Summary of the quasiPoisson regression model for annual tick density

\begin{tabular}{lllll}
\hline & Estimate & $\mathrm{SE}$ & $\mathrm{z}$ & $\mathrm{p}$ \\
\hline Intercept & 2.5404 & 0.7031 & 3.613 & $<0.05$ \\
$\mathrm{~T}_{D J F}$ & 0.0911 & 0.0315 & 2.893 & $<0.05$ \\
$\mathrm{~T}_{\text {year }-1}$ & 0.2591 & 0.0706 & 3.672 & $<0.05$ \\
$\mathrm{~F}_{\text {year }-2}$ & 0.2440 & 0.0351 & 6.959 & $<0.001$ \\
\hline
\end{tabular}

For the explanatory variables mean winter temperature $\left(\mathrm{T}_{D J F}\right)$, mean annual temperature of the previous year $\left(\mathrm{T}_{\text {year }-1}\right)$, and the beech fructification index 2 years prior $\left(\mathrm{F}_{\text {year }-2}\right)$ the parameter estimates, the standard errors SE, the z-values (test statistics), and the p-values (significance) are given

can be evaluated by independent data, when observations will be available at the end of the year 2018.

In a pilot study, the same model was already used to forecast the annual nymphal tick density for the year 2017. As presented at the $19^{\text {th }}$ Annual Meeting of the International Scientific Working Group on Tick-Borne Encephalitis (Kunze and ISW-TBE 2017), a relatively low tick density of 187 ticks per $100 \mathrm{~m}^{2}$ was predicted for Haselmühl in March 2017 (Brugger et al. 2017b) and evaluated with 180 collected ticks per $100 \mathrm{~m}^{2}$ at the end of 2017. So far, this can be considered as the most robust model evaluation based on model-independent observations. A limitation of the model, however, is its statistical nature implying that it was fitted to the specific location of Haselmühl (Bavaria, Germany). Therefore, it is not generally applicable and needs individual adjustment when applied to other sites.

\section{Discussion}

Using the long-term monitoring of I. ricinus in Haselmühl, it was demonstrated that the fructification index as well as time-lagged temperature means are appropriate predictors for the annual nymphal tick density. Even more, by the end of the winter time, i.e. at the end of February, a forecast of the tick density for the upcoming year can be made. Especially, mast seeding, i.e. full fructification, turned out to be an appropriate predictor for the annual nymphal tick density. Mast seeding of beeches sets off a chain of ecological reactions (Kelly 1994; Ostfeld et al. 1996). The effects of seeding from the perspective of ticks and tick-borne pathogens is outlined in Fig. 2. As an optimal food source, a magnitude of beech nuts attracts large mammals as roe deer (Capreolus capreolus) or wild boar (Sus scrofa), which are common hosts for female I. ricinus (Gray et al. 2016). As a consequence, this boosts the density of larvae in the following summer. Coincident, the abundant beech nuts benefit an increased survival and breeding of small rodent populations mainly Myodes spp. or Apodemus spp., which are suitable hosts for I. ricinus larvae. Together with a moderate annual temperature in the preceding year and warmer winter temperatures this culminates after moulting from larvae to nymphs and successful overwintering in higher nymphal densities 2 years after mast seeding. Such population peaks can result in an increased risk for humans to acquire tick-borne pathogens causing e.g. TBE or LB. The relation between mast seeding, the subsequent increase of mouse populations and disease incidence one or two years later 


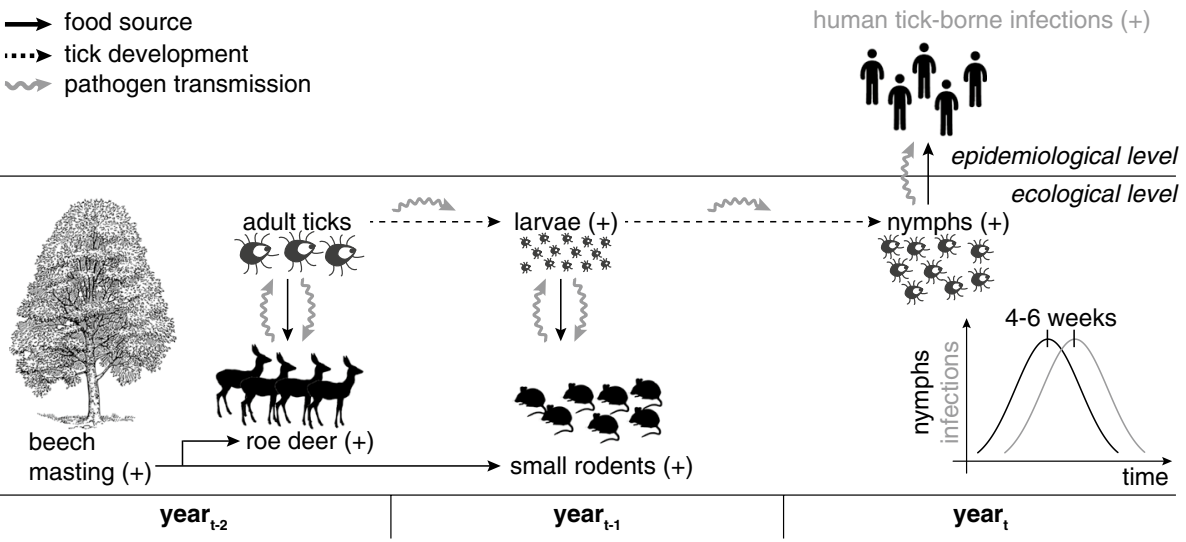

Fig. 2 The effect of mast seeding on Ixodes ricinus and the possible transmission of tick-borne pathogens. An increase is indicated by $(+)$

has been already shown e.g. for human Lyme disease in the Eastern USA (Jones et al. 1998; Schauber et al. 2005) and Poland (Bogdziewicz and Szymkowiak 2016), or Puumala virus infections in Germany (Reil et al. 2015).

As an alternative to the fructification index, the small rodent density or hunting statistics can be applied directly as biotic predictors. For Germany, several time series are available e.g. for field voles (Microtus agrestis) or bank voles (Myodes glareolus) some of which go back to 1952 (Imholt et al. 2017). However, these data sets were not used in the current study, as the observation periods available for the voles did not match those available for I. ricinus. Furthermore, the fructification index is optimal as it is synchronised over both large areas and climate zones (Vacchiano et al. 2017).

A reliable forecasting of the annual tick density can also provide a first estimate of the risk for acquiring a tick-borne pathogen and the related human incidences. In Germany, the large majority of human TBE cases was reported each year in the southern federal states, especially in Bavaria (Robert Koch Institute 2018). A total of 1,361 TBE cases were registered in Bavaria between 2009-2017. The correlation between the annual tick densities in Haselmühl and the TBE cases in Bavaria is relatively high for the period 2009-2016 $\left(\mathrm{r}_{S}=0.73, \mathrm{p}<0.05, \mathrm{n}=8\right)$. However, with the increase of TBE cases in 2017 the correlation drops notably $\left(\mathrm{r}_{S}=0.46, \mathrm{p}=0.21, \mathrm{n}=9\right)$. This unexpected increase of TBE cases in 2017 not only on district level but also on federal state level is inexplicable. One possible explanation is the result of the culmination of annual cycles of different length coinciding (Zeman 2017). Nevertheless, the extraordinarly high number of TBE cases reported in 2017 shows the limitations of correlative models. If a so far unidentified factor or circumstance is not considered, a reliable TBE forecast is not possible yet. One missing predictor might be hunting statistics, as already demonstrated with TBE forecasts based on statistical models for Sweden (Haemig et al. 2011) or Germany (Kiffner et al. 2010). On the other hand also the "good" mushroom season in 2017 could have an effect on the TBE incidences (Jaenson et al. 2012).

Generally, such long-range forecasts of I. ricinus densities are essential for epidemiological considerations: not only for individuals at risk of acquiring a pathogen capable of causing TBE or LB, but also for public health authorities. 
Acknowledgements Open access funding provided by University of Veterinary Medicine Vienna. The tick monitoring was supported in part by a German Center of Infection Research (DZIF) Grant. The study was partly financed by Pfizer Deutschland GmbH. Please note, that both funders had no role in study design, data collection, analysis, interpretation, decision to publish, or preparation of the manuscript. The authors are very grateful to Olaf Kahl for critical reading the manuscript and his valuable hints.

Open Access This article is distributed under the terms of the Creative Commons Attribution 4.0 International License (http://creativecommons.org/licenses/by/4.0/), which permits unrestricted use, distribution, and reproduction in any medium, provided you give appropriate credit to the original author(s) and the source, provide a link to the Creative Commons license, and indicate if changes were made.

\section{References}

Beugnet F, Chalvet-Monfray K, Loukos H (2009) FleaTickRisk: a meteorological model developed to monitor and predict the activity and density of three tick species and the cat flea in Europe. Geospat Health 4:97-113. https://doi.org/10.4081/gh.2009.213

Bogdziewicz M, Szymkowiak J (2016) Oak acorn crop and Google search volume predict Lyme disease risk in temperate Europe. Basic Appl Ecol 17(4):300-307. https://doi.org/10.1016/j.baae.2016.01.002

Brugger K, Boehnke D, Petney T, Dobler G, Pfeffer M, Silaghi C, Schaub GA, Pinior B, Dautel H, Kahl O, Pfister K, Süss J, Rubel F (2016) A density map of the tick-borne encephalitis and Lyme borreliosis vector Ixodes ricinus (Acari: Ixodidae) for Germany. J Med Entomol 53:1292-1302. https://doi. org/10.1093/jme/tjw116

Brugger K, Walter M, Chitimia-Dobler L, Dobler G, Rubel F (2017a) Seasonal cycles of the TBE and Lyme borreliosis vector Ixodes ricinus modelled with time-lagged and interval-averaged predictors. Exp Appl Acarol 73:439-450. https://doi.org/10.1007/s10493-017-0197-8

Brugger K, Walter M, Chitimia-Dobler L, Dobler G, Rubel F (2017b) Forecasting the tick-borne encephalitis vector Ixodes ricinus in space and time, Poster presented at the 19th annual meeting of the International Scientific Working Group on Tick-Borne Encephalitis (ISW-TBE), Vienna (Austria), 29-30 May 2017. http://iissrv1.vu-wien.ac.at/i136/BRUGGER/pdf/ISW-TBE_2017.pdf

Clement J, Vercauteren J, Verstraeten WW, Ducoffre G, Barrios JM, Vandamme AM, Maes P, Van Ranst M (2009) Relating increasing hantavirus incidences to the changing climate: the mast connection. Int J Health Geogr 8:1. https://doi.org/10.1186/1476-072X-8-1

Daniel M, Vráblík T, Valter J, Křiž B, Danielová V (2010) The TICKPRO computer program for predicting Ixodes ricinus host-seeking activity and the warning system published on websites. Cent Eur J Public Health 18(4):230-236

Daniel M, Malỳ M, Danielová V, Kř́ž B, Nuttall P (2015) Abiotic predictors and annual seasonal dynamics of Ixodes ricinus, the major disease vector of Central Europe. Parasit Vectors 8(1):478. https://doi. org/10.1186/s13071-015-1092-y

Eichhorn J, Roskams P, Potočić N, Timmermann V, Ferretti M, Mues V, Szepesi A, Durrant D, Seletković I, Schröck HW, Nevalainen S, Bussotti F, Garcia P, Wulff S (2017) Part IV: Visual assessment of crown condition and damaging agents. In: UNECE ICP Forests Programme Co-ordinating Centre (ed) Manual on methods and criteria for harmonized sampling, assessment, monitoring and analysis of the effects of air pollution on forests, Thünen Institute of Forest Ecosystems, Eberswalde, Germany

Garcia-Martí I, Zurita-Milla R, van Vliet AJH, Takken W (2017) Modelling and mapping tick dynamics using volunteered observations. Int J Health Geogr 16:41. https://doi.org/10.1186/s12942-017-0114-8

German Weather Service (2018) Climate data Germany. http://www.dwd.de/DE/leistungen/klimadatendeuts chland/klimadatendeutschland.html. Accessed $01 \mathrm{Feb} 2018$

Gray JS (1998) The ecology of ticks transmitting Lyme borreliosis. Exp Appl Acarol 22:249-258. https:// doi.org/10.1023/A:1006070416135

Gray JS, Kahl O, Lane RS, Levin ML, Tsao JI (2016) Diapause in ticks of the medically important Ixodes ricinus species complex. Ticks Tick-Borne Dis 7:992-1003. https://doi.org/10.1016/j.ttbdi s.2016.05.006

Haemig PD, Sjöstedt de Luna S, Grafström A, Lithner S, Lundkvist A, Waldenström J, Kindberg J, Stedt J, Olsén B (2011) Forecasting risk of tick-borne encephalitis (TBE): using data from wildlife and climate to predict next year's number of human victims. Scand J Infect Dis 43:366-372. https://doi. org/10.3109/00365548.2011.552072

Imholt C, Reil D, Plašil P, Rödiger K, Jacob J (2017) Long-term population patterns of rodents and associated damage in German forestry. Pest Manag Sci 73:332-340. https://doi.org/10.1002/ps.4325 
Jaenson TGT, Hjertqvist M, Bergström T, Lundkvist A (2012) Why is tick-borne encephalitis increasing? A review of the key factors causing the increasing incidence of human TBE in Sweden. Parasit Vectors 5:184. https://doi.org/10.1186/1756-3305-5-184

Jones CG, Ostfeld RS, Richard MP, Schauber EM, Wolff JO (1998) Chain reactions linking acorns to gypsy moth outbreaks and Lyme disease risk. Science 279:1023-1026

Kelly D (1994) The evolutionary ecology of mast seeding. Trends Ecol Evol 9:465-470. https://doi. org/10.1016/0169-5347(94)90310-7

Kiffner C, Zucchini W, Schomaker P, Vor T, Hagedorn P, Niedrig M, Rühe F (2010) Determinants of tickborne encephalitis in counties of southern Germany, 2001-2008. Int J Health Geogr 9:42. https://doi. org/10.1186/1476-072X-9-42

Kronnert M, Schneck D, Zollner A (2016) Blühen und Fruktifizieren unserer Waldbäume in den letzten 60 Jahren. LWF Wissen 74:37-45

Kunze U, ISW-TBE (2017) Report of the 19th Annual Meeting of the International Scientific Working Group on Tick-Borne Encephalitis (ISW-TBE) - TBE in a changing world. Ticks Tick-Borne Dis. https://doi.org/10.1016/j.ttbdis.2017.08.009

Mihalca AD, Sándor AD (2013) The role of rodents in the ecology of Ixodes ricinus and associated pathogens in Central and Eastern Europe. Front Cell Infect Microbiol 3:56. https://doi.org/10.3389/fcimb .2013 .00056

Ostfeld RS, Jones CG, Wolff JO (1996) Of mice and mast. BioScience 46:323-330. https://doi. org/10.2307/1312946

R Development Core Team (2018) R: a language and environment for statistical computing, R Foundation for Statistical Computing, Vienna, Austria, ISBN 3-900051-07-0. Version 3.3.1. http://www.R-proje ct.org/

Reil D, Imholt C, Eccard JA, Jacob J (2015) Beech fructification and bank vole population dynamics-combined analyses of promoters of human Puumala virus infections in Germany. PloS ONE 10(e0134):124. https://doi.org/10.1371/journal.pone.0134124

Robert Koch Institute (2018) SurvStat@RKI 2.0, https://survstat.rki.de. Accessed 01 Feb 2018

Schauber EM, Ostfeld RS, Evans AS Jr (2005) What is the best predictor of annual Lyme disease incidence: weather, mice, or acorns? Ecol Appl 15(2):575-586. https://doi.org/10.1890/03-5370

Takken W, van Vliet AJH, Verhulst NO, Jacobs FHH, Gassner F, Hartemink N, Mulder S, Sprong H (2017) Acarological risk of Borrelia burgdorferi sensu lato infections across space and time in The Netherlands. Vector Borne Zoonotic Dis 17:99-107. https://doi.org/10.1089/vbz.2015.1933

Vacchiano G, Hacket-Pain A, Turco M, Motta R, Maringer J, Conedera M, Drobyshev I, Ascoli D (2017) Spatial patterns and broad-scale weather cues of beech mast seeding in Europe. New Phytol 215:595608. https://doi.org/10.1111/nph.14600

World Meteorological Organization (2010) Manual on the global data-processing and forecasting systemGlobal aspects. WMO-No. 485

Zeman P (2017) Cyclic patterns in the central Europe tick-borne encephalitis incidence series. Epidemiol Infect 145:358-367. https://doi.org/10.1017/S0950268816002223

Zhang D (2016) rsq: Coefficient of determination, R package version 0.6

Zuur AF, Ieno E, Walker N, Saveliev A, Smith G (2009) Mixed effects models and extentions in ecology with R. Statistics for biology and health. Springer, New York 